\title{
A Relationship between Social Media Platforms and the Financial Success of Modern African Entrepreneurs
}

\author{
Celestine L. Ukpere ${ }^{1}$ \\ Andre D Slabbert ${ }^{1}$ \\ Wilfred Ukpere ${ }^{2}$ \\ ${ }^{1}$ Cape Peninsula University of Technology, P.O Box 652, Cape Town 8000, South Africa. \\ Email: cukprere@gmail.com \\ ${ }^{2}$ Department of Industrial Psychology and People Management, \\ Faculty of Management, University of Johannesburg, Johannesburg, South Africa \\ E-mail:wikpere@uj.ac.za
}

Doi:10.5901/mjss.2014.v5n4p479

\section{Abstract}

Globalisation, technological developments, and corporate mergers and acquisitions have brought fundamental changes to the modern entrepreneurial landscape. Reduced data bundle rates, the expansion of telecommunications, and the increased use of the Internet in Africa are the main driving forces. In recent times, African entrepreneurship has been in a constant state of development and flux. This paper reports the findings of an online survey conducted in Africa in 2013, investigating the experiences of entrepreneurs on the continent in adapting and incorporating online social network platforms and digital tools in both the formal and informal sectors. In recent times, African entrepreneurs have realised that the empowered, sophisticated, critical and well-informed society living on the continent in the present day is different from that of the previous post-colonial era. The Internet (and more recently social media enabled through Web2.0) has enabled the business community at large to control information and have power over the marketing process, with concomitant dilemmas and challenges for African entrepreneurs. This paper explains what role the new face of the Internet, widely referred to as Web2.0 or social media has played in unlocking this vast potential in terms of enabling the economic survival and success of modern African entrepreneur. Embracing social media platforms and tools facilitates entrepreneurship through the creation of competitive advantages that build prosperity in the modern global economy. Social-media platforms are therefore important strategic marketing tools for entrepreneurs.

Keywords: Social media, Web 2.0, Technology, e-Commerce, m-Commerce, e- Marketing

\section{Introduction}

The growth and success of entrepreneurship in sub-Saharan Africa is reflected in the role played by budding entrepreneurs in the promotion and creation of wealth, and in improving the living standards of ordinary Africans. Social restrictions and economic obstacles are removed through the economic actions of entrepreneurs (Legatum Institute 2011). The development of African economies is accelerated by two important factors, namely entrepreneurship and local private enterprise. Entrepreneurship and local private enterprise are crucial components of African economic development (Legatum 2011). Innovation, risk assumption, hiring and management of labour, opening up of markets, and combining new raw materials and processes to manufacture new products, which aids economic development. Entrepreneurs encourage the regulation of active economies through the changes they initiate (Legatum Institute 2011).

There is a strong relationship between the entrepreneurial factors of low business start-ups and ICT infrastructure (mobile, Internet), which are linked to higher levels of average income and wellbeing; this has been supported through global statistical studies. Countries with a developed ICT infrastructure are prone to have higher levels of income (Legatum Institute 2011).Two areas that can be mechanisms for change as identified by the 2010 Legatum Prosperity Index are ICT development and increased access to opportunity (Legatum Institute 2011). Social media platforms and ICT have been recognised by modern African entrepreneurs as their key to unlocking financial success. Most business owners accept the growth of social media platforms such as Facebook, Linkedln and Twitter, and have embraced them in building their brand and product awareness (Green 2011). 


\section{Factors Affecting Entrepreneurship through Technology in Africa}

Entrepreneurs in Africa have always been viewed with distrust by the rest of the global world owing to their reluctance to embrace technology as a tool for business growth. Social media puts to test most hypotheses regarding how businesses should communicate with their communities. The most significant modification to comprehend and acknowledge is that most communities now have the capacity to interact with one another and with the businesses they support. Historically, those dialogues have been restricted to few hundreds of people. Today, communication is worldwide and comprises millions of voices. Once a change like this is effected, considerable transformation ensues, both expected and unexpected. Therefore, the effectiveness of social media platforms in business growth and expansion for the modern African entrepreneur should not be ignored.

Modern African entrepreneurs have been slow in adopting web-based trends because of a poor ICT infrastructure. Therefore, they have been slow to employ the social media campaigns that other entrepreneurs have adopted worldwide. Hence, addressing how social platforms contribute to the growth and expansion of business in Africa will enable one to know the impact of the continent's investment in social media. It should be questioned whether each social platform utilised and its effect on business are monitored adequately.

According to Webster (1992), practical proficiencies, including IT, are essential to conduct marketing operations, "The core firm will be defined by its end-use market and its knowledge base, as well as its technical competence, not by its factories and its office buildings. Customer focus, market segmentation, targeting and positioning, assisted by information technology, will be the flexible bonds that hold the whole thing together" (Saren 2011). The modern knowledge economy depends on ICT for its support. In the late 1990s, approximately two-thirds of the USA's increase in growth production came from the ICT sector (Coyle 2001). The process of manufacturing has been changed through the huge benefits of ICT. This is seen through links to suppliers and customers, and companies have reduced their inventories, since they have a better idea of what they need and when. This has led to reduced costs, improved customer service, and has rendered business processes in industrialised countries less unstable (Coyle 2001). ICT is therefore an important indicator of a country's ability to develop and grow economically (Luiz 2010).

The research has been carried out on both formal and informal businesses that have embraced the World Wide Web, or social media platforms, or both. Formal and informal businesses can be found throughout Africa, and thanks to the power of the Internet and social media platforms, which has made the search for diverse entrepreneurship ventures less cumbersome. Both informal and formal entrepreneurs who have embraced the Internet and social media platforms can be observed, documented and compared. This enables an understanding of the role played by the Internet and social media platforms in the growth, expansion and success of entrepreneurs in Africa, especially those who are well versed in the rules and applications of online that enable them to outstrip their peers through social platforms. How are modern African entrepreneurs willing to invest resources in social media to the advantage of their ventures? These aspects, when critically studied, will enable both established and emerging entrepreneurs to realise that just being on the social media platform will not grow their businesses, but taking an active role communicating through these platforms is critical to their growth and expansion. With the Internet becoming a fundamental part of daily life in Africa, and especially in Kenya, people are changing the way they communicate, shop, work, research and even socialise, as attested by Olga Arara-Kimani (cited in Mulunda 2012).

Dash2do is a mobile application that promotes e-commerce and m-commerce through an online platform with an existing portfolio of informal workers who carry out daily tasks for very busy professionals. The informal workers, pay the company $30 \%$ of their fees, and payment is through credit cards, PayPal for the diaspora Kenyans and M-Pesa for locals (AfricaReport 2013). Adopting and implementing technology in terms of mobile phones through data based operations reduces costs leading to reduction in poverty in societies (Karrer-Rueedi Trueb 2011). Women and the disadvantaged in society have been empowered through the use of mobile phones that have enabled easy communication, market access, and sales of products globally, through reaching more consumers and making use of mobile payments (West 2012).

Entrepreneurship workshops and training taking place in Africa have recently increased. The majority of young graduates are choosing to take risks and start entrepreneurial ventures rather than seek employment, as has been the norm after graduation; thus becoming an entrepreneur is 'the next big thing' on the continent. These modern African entrepreneurs have met with general acceptance, although this is a recent phenomenon in Africa. The former expectations of university graduates in pursuing their dreams and passions, no matter how small, were generally those of working in a bank, large firm, factory or institution; this, however, has changed. Many young entrepreneurs, from Lagos to Nairobi, are less interested in what is occurring in their own neighbourhoods but quite motivated by what is taking place in Silicon Valley. There are three categories of people in the African social media sector. The first works to 
duplicate what is already present, for example, Facebook and Twitter. The second builds up constructive technologies and makes them available for free. The third is at the centre of the entrepreneurial category of feasible business ideas (Ekekwe 2011). High impact financiers predominantly focus on small and medium-sized enterprises (SMEs) as a way of dealing with a variety of issues such as youth employment, and access to utilities, housing, renewable energy, and health. Studies prove that formal SMEs contribute around 45\% of employment and 33\%of the GDP in developing economies (Kanaiya 2011). SMEs in the USA have adopted social media to attract new customers and retain old ones. The social platforms used are depicted in Figure 1 below.

Figure 1: Social media tools used by SMEs in the USA to attract new consumers: 2010 - 2011

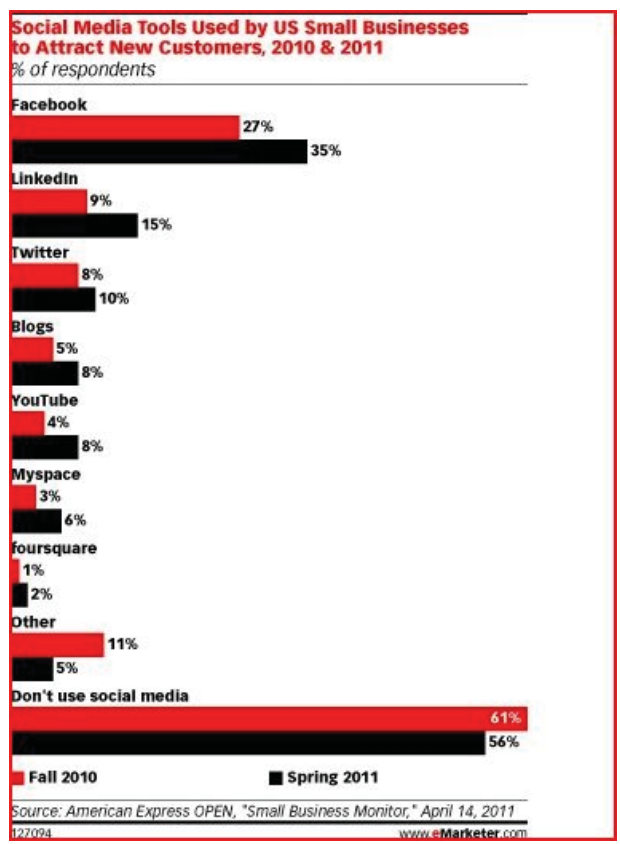

Source: Reed (2011)

It has been observed globally that women entrepreneurs are achieving an entrepreneurial stronghold in e-commerce through social media platforms. Clients with disposable earnings are targeted with the aid of digital marketing and platforms, especially social media platforms and sold luxury products by female-empowered ventures in the category of Business to Consumer (B2C) e-commerce enterprises. The integrity of most of these $\mathbf{B 2 C}$ ventures is validated through proper delivery infrastructures for the merchandise or services, and because their clients are in developed countries, their e-commerce, social media platform-driven ventures are successful (Padmannavar 2011). This clearly depicts that obstacles are being overcome by female-owned ventures, enabling them to achieve an international presence. The rate at which women-run ventures are passionately embracing and adopting networking and digital opportunities through social media platforms, is crucial to their growth and expansion. Research has confirmed that through the incorporation and use of social media marketing in conjunction with traditional business methods, women entrepreneurs have been able to deal better with the recession than male ones (Johnson-Elie 2013). This is as a result of female entrepreneurs' embracing of, investing in and adapting to new social media platforms, thereby creating an SME social media revolution, while their male counterparts are sluggish.

Statistically, as noted by American Express, $37 \%$ of male entrepreneurs use at least one type of social media tool in their ventures, compared with $43 \%$ of female entrepreneurs. Female entrepreneurs focus on increasing their use of social media, while male entrepreneurs typically focus on investment in training and staff, rather than in digital technology through social media. In a survey, female entrepreneurs contended that they used Facebook to generate sales and communicate with their clients, and they had more Twitter accounts compared with their male counterparts. Forty-eight 
per cent of women, compared with $40 \%$ of men, enabled their company websites for online commerce. HootSuite has proved that in North America, more women are using social media than men; this online dominance has enabled them to have formidable power in influencing the online opinions that drive e-commerce (online shopping). It is a fact that social media marketing leads to growth in small and medium-sized businesses, since it is both an effective and inexpensive tool. It results in positive outcomes at a fraction of the cost of more traditional marketing programmes, if implemented correctly. It is possible that women's willingness to embrace social media marketing stems from the same impulses that make them more likely to embrace the greater Web. They continue to drive the commercial side of online activity, and are more likely to use social media to share and educate, resulting in their being more likely to embrace new technology (Johnson-Elie 2013).

Caroline Ceniza-Levine is a validated example of a woman business owner, who, through leveraging social media platforms, has taken her entrepreneurial venture to the next level. Ceniza-Levine has been recognised in the four years of her venture's existence, for increasing her output by $600 \%$, which she attributes to the aggressive use of social media platforms in building a strong public profile and vigorous marketing tactics. This has enabled her to take advantage of high-profile opportunities and be featured as a guest on Fox Business, CBS, and CNN, resulting in increased sales and revenue, as well as a new client base. The use of social media has enabled female entrepreneurs to cement interpersonal relationships, and to know (and trust) clients better, leading to concrete and substantial business interactions. A presence on social media outlets is crucial, as it facilitates meeting people and growing one's client base (Johnson-Elie 2013). A 2011 survey done by The Guardian Life Small Business Research Institute confirmed the ability of female entrepreneurs being more likely to embrace social media than their male counterparts; they were also three times more likely to engage in social networking than male entrepreneurs. This was as a result of women having a sense of community incorporated into their business plans, which enables them to be more customer-focused (Weeks 2010). More female entrepreneurs are being encouraged to operate through social media platforms and spaces, especially in today's digital age, and use them to their advantage.

These illustrations from developed economies have enabled most modern African entrepreneurs to embrace technology and IT, especially through social media platforms as a key to unlock the door to financial success in their ventures. Social media platforms are considered big business around the globe, and this is depicted in Figure2 below.

Figure 2: Screenshot of the strength of social media in percentages

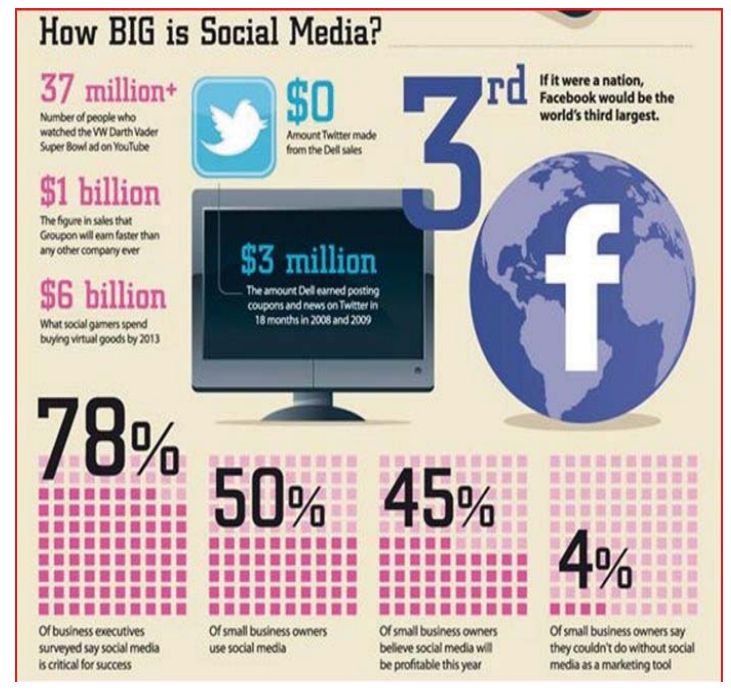

Source: Green (2011)

Development in mobile IT relies on four key factors: service providers, customers, competitors and regulatory bodies. Customer empowerment within the mobile economy is based on the customer's responsibility in the value chain procedure (Saren 2011). Africa has approximately 616 million mobile users (Juma 2011). Massive and abundant 
opportunities in social and economic development have occurred with the increase in the use of wireless devices (West 2012). This has been proved through leapfrog technology on the African continent, enabling improved access to finance, lower transaction costs and data relevant to business growth. These factors facilitate economic and social development in communities. There is therefore sufficient evidence that entrepreneurs in the informal sectors can become active participants in the formal economy with the right tools (Karrer-Rueedi \& Trueb 2011). The Kenyan mobile operator Safaricom's success with mobile money has encouraged economists, governments and organisations to exploit opportunities from a hitherto untapped source- people in developing economies without bank accounts. Electronic payments and transmission of money have economically uplifted communities, particularly women (Kusimba et al. 2013). In developing economies the mobile phone is currently the predominant mode of business communication and transaction. Its use as an ICT device has increased dramatically (Komunte et al. 2012).

The Omidyar Network has financially and organisationally invested in many ventures that relate to mobile technology. They accept there is still much to be researched and accomplished through these new technologies. Recent events have demonstrated rapid technological change (Gollamudi 2012). In 2012, the World Bank released a report illustrating the enthusiasm engendered in developing economies through mobile commerce (WorldBank 2012). ICT development and improved access to opportunities jointly facilitate the strengthening of economic development. M-Pesa ( $M$ stands for mobile, pesa is Swahili for money) is a money transfer service by mobile phone, initiated by mobile network operators in Kenya. An African initiative (with many imitators like Orange Money, Airtel Money and Yu Cash), which epitomises the continent's efforts to engage with ICT development and provide access to credit by making it possible for people to have money through their mobile phones. It is important to acknowledge the role these efforts that demonstrate the best of African entrepreneurship through ICT, play in advancing the prospects of other promising entrepreneurs. "For example, M-Pesa has led to new opportunities for existing and new businesses that have been able to take advantage of growing local demand for goods and services. That new demand has been driven by increased money circulation through M-Pesa, and lower transactions costs for vendors using M-Pesa to obtain their stock" (Legatum Institute 2011).

Numerous reasons for SMEs' tardy adoption of ICT include lack of time, resources, etc. Social media adoption has been slow but is happening gradually. A report from the American Express OPEN ${ }^{\circledR}$ Small Business Monitor (as reported by e-Marketer) indicates that the move towards the adoption of social media as a vital part of the SMEs' marketing range over the past years has increased (Reed 2011). Social media is gaining a greater foothold among SMEs. Suggestions have been made on how to make the best use of social media platforms to improve business, and the information is available free of charge online (see Figure 3). This has also enabled modern African entrepreneurs to educate themselves on harnessing this type of media for business growth and expansion.

Figure 3: Screenshot of tips for using social media for business success

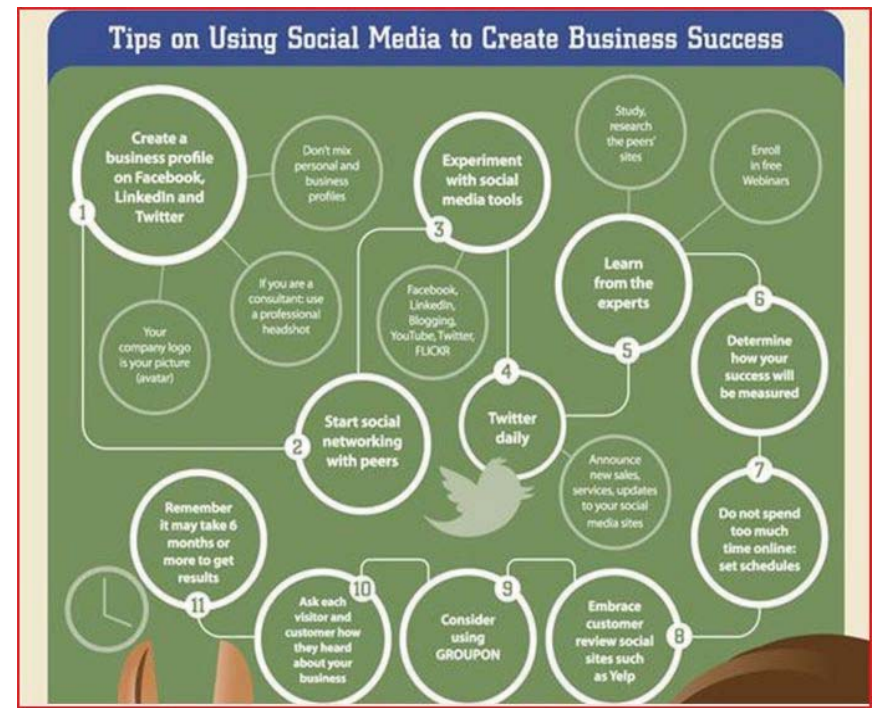

Source: Green (2011) 
Most entrepreneurs surveyed did not consider a university education a requirement for starting and running business ventures and do not possess one. They considered social skills and networks as high factors, with $41 \%$ of entrepreneurs ranking themselves as 'very good' at making conversation and 31\% always looking to expand their social networks. Only $27 \%$ of non-entrepreneurs rated themselves as good at making conversation and $15 \%$ sought to develop their list of friends. People skills and team work are a third requirement of a successful entrepreneur, with $82 \%$ of the entrepreneurs reviewed in the Kauffman Report ranking their management teams as 'important' to their success and 35\% rating them as 'very important'. At the core of the report, awareness and attitudes to change have been emphasised. According to the late Peter Drucker, "The entrepreneur always searches for change, responds to it and exploits it as an opportunity" (Michira 2011).

Figure 4: Online marketing tactics by SMEs in the US: 2007 - 2011

\begin{tabular}{|c|c|c|c|c|}
\hline \multicolumn{5}{|c|}{$\begin{array}{l}\text { Online Marketing Tactics Currently Used by US } \\
\text { Small Businesses, } 2007-2011 \\
\% \text { of respondents }\end{array}$} \\
\hline & $\begin{array}{l}\text { Fall } \\
2007\end{array}$ & $\begin{array}{c}\text { Spring } \\
2009\end{array}$ & $\begin{array}{l}\text { Fall } \\
2009\end{array}$ & $\begin{array}{l}\text { Spring } \\
2011\end{array}$ \\
\hline A company website & $55 \%$ & $54 \%$ & $49 \%$ & $65 \%$ \\
\hline Search engine optimization & $26 \%$ & $22 \%$ & $20 \%$ & $36 \%$ \\
\hline Mass email & $18 \%$ & $22 \%$ & $13 \%$ & $24 \%$ \\
\hline $\begin{array}{l}\text { Online social networking } \\
\text { (Myspace, Facebook, etc.) }\end{array}$ & $11 \%$ & $13 \%$ & $15 \%$ & $35 \%$ \\
\hline $\begin{array}{l}\text { Pay-per-click advertising } \\
\text { (Google AdWords, etc.) }\end{array}$ & $11 \%$ & $11 \%$ & $9 \%$ & $17 \%$ \\
\hline Banner ads/pop-up ads & $8 \%$ & $8 \%$ & $5 \%$ & $11 \%$ \\
\hline Blog & $5 \%$ & $7 \%$ & $3 \%$ & $12 \%$ \\
\hline podcasts & $2 \%$ & $3 \%$ & $1 \%$ & $3 \%$ \\
\hline \multicolumn{5}{|c|}{ Source: American Express OPEN, "Small Business Monitor," April 14, 2011} \\
\hline$\overline{27093}$ & & & wwote & rketer.con \\
\hline
\end{tabular}

Source: Reed (2011).

\section{Observations on the use of some Social media platforms in Africa}

Online data observed comprised data obtained from the three African regions of southern, West and East Africa, from three entrepreneurs who use the social platform of Facebook for marketing, and for communication with their client base or 'following'. This was done through the Internet. The countries for the source of data collection are the main economic powerhouses of each region.

In the southern region, South Africa was identified, while in East Africa, Kenya, and in West Africa, Nigeria, were targeted, and links of their pages taken into account. The Internet was the appropriate means of obtaining relevant information, since it is easy to access, inexpensive, and data and evidence are easily retrievable through social network links. Two retail or product-based businesses were identified from each region. A service-based business/venture, basically in music or writing, was also included in each region. Each region has three targeted cases, with accompanying screenshots.

\subsection{Southern Africa}

$2^{\text {nd }}$ Take is a Cape Town-based, second-hand, authentic design retailer that stocks international and local brand names. It is three years old, and has a physical store and an online store; it has embraced the Internet and social media platforms to interact with both its existing customer base and prospective clients. (2 ${ }^{\text {nd }}$ Take link: https://www.facebook.com/\#!/2ndTake?fref=ts)

TAKEALOT is a Cape Town-based, e-commerce online store that has been in existence for a while, and does not have a physical retail store. It has both a very strong web presence and a presence on all the relevant and important social media platforms (TAKEALOT link: https://www.facebook.com/\#!/Takealot)

The Parlotones are a world-famous South African brand that has incorporated the Internet and social media platforms to enable access to their fans, and to market and advertise their upcoming performances and their new music releases or CD sales. They have a strong web presence on all the major platforms and use the social applications to keep their fan base and community informed of their projects, albums and tours. (Parlotones link: 
https://www.facebook.com/\#!/theparlotones?fref=ts)

\subsection{West Africa}

Bayo Shoesale Adedeji is a Nigerian, Lagos-based entrepreneur, who sells shoes in various Nigerian towns through holding shoe sales once a month. He has a physical retail shop in Lagos, an Internet presence, and relies on the social media platform of Facebook to advise his current and prospective clients when and where the next shoe sale will take place, and what shoes will be available during the sales. (Bayo Shoesale Adedeji link: https://www.facebook.com/shoesale?refid=46)

Sumbo Bewaji Abiola is a Nigerian ethnic fashion designer who is based in Baltimore, Maryland, in the USA, and most of her clientele are the Nigerian professional expatriate and Lagos-based, well-travelled communities. She makes clothes on order for occasions such as traditional weddings, engagements, birthdays, funerals, etc., and has an Internet presence. She relies on the social media platform of Facebook to inform her current and prospective clients of her next fashion shows or latest creations. (Sunmbo Bewaji Abiola link: https://www.facebook.com/\#!/BEWAJl?fref=ts)

The late Chinua Achebe was a Rhode Island-based scholar and world-renowned author, with both an Internet and social platform presence through online links on his publisher, Random House's website, which is still in operation. (Chinua Achebe author link: https://www.facebook.com/\#!/ChinuaAchebeAuthor)

\subsection{East Africa}

Ujenzi Bora is a company that deals with properties, real estate and construction, and is based in Nairobi, Kenya. It has a physical office and strong web and social platform presence. (Ujenzi Bora link: https://www.facebook.com /pages/Ujenzibora/154148887961737)

Zambu Deals, Kenya, is a purely online, Internet-based business that incorporates other previously established groups under one umbrella, the Zambu Deals platform. The other companies incorporated include Rupudeals, Zetudeals, Mocalitydeals. All these companies sell services and products at discounted rates, through group buying via a daily deals marketing strategy. Zambu Deals is relatively new, having been launched in September 2011, but the companies under the Zambu umbrella have been in business for some time. They have an Internet and social media platform presence, and rely solely on these to advertise their daily deals and obtain bookings and orders from clients interested in group buying. (Zambu-Kenya link:https://www.facebook.com/\#!/pages/Zambu-Kenya/197881180276373).

Eric Wainaina is a renowned Kenyan musician who relies on the Internet and social platforms to keep his fan base and prospective followers aware of his current and forthcoming performances, both internationally and in Kenya, and to advertise and market his brand.(Eric Wainaina link: https://www.facebook.com/ericwainainamusic). Table 1 depicts the selected databases and their online and social media presence on the two platforms of Facebook and Twitter. Included in the table are the data pertaining to their Twitter handles, and their Facebook and Web domain names.

Table1: Social media platforms embraced by African entrepreneurs

\begin{tabular}{|l|l|l|l|}
\hline \multicolumn{1}{|c|}{$\begin{array}{c}\text { Southern Africa } \\
\text { South Africa }\end{array}$} & Twitter Handles & \multicolumn{1}{c|}{ Facebook } & Website \\
\hline 2nd Take & 2nd_Take & 2nd Take Business Page & www.2ndtake.co.za \\
\hline TAKEALOT & TAKEALOT & Takealot - Retail & www.takealot.com \\
\hline The Parlotones & parlotones & The Parlotones -Musicians/Band & www.parlotones.com \\
\hline East Africa Kenya & Twitter & Facebook & Website \\
\hline Ujenzi Bora & UjenziBora & Ujenzibora - Business & www.ujenzibora.com \\
\hline Zambu Deals & zambudeals & Zambu-Kenya - Business & www.zambu.co.ke \\
\hline Eric Wainaina & ericwainaina & Eric Wainaina -Musician/Band & www.ericwainaina.com \\
\hline West Africa Nigeria & Twitter & Facebook & Website \\
\hline Bayo Adedeji Mega Shoesale & N/A & Bayo Shoesale Adedeji (Mega Shoe Sale) - Personal & www.megashoesaleinc.com \\
\hline Sumbo Bewaji Abiola & N/A & Sumbo Bewaji Abiola - Personal & www.bewaji.com \\
\hline Chinua Achebe & randomhouse & Chinua Achebe - Author & www.randomhouse.com \\
\hline
\end{tabular}




\section{Discussion}

South Africa is the economic power house of Africa, with entrepreneurs who are very up to date regarding the use of social tools and their applications, especially through the use of the Internet and social media platforms, to enhance their businesses. South African retailers make use of online payments and Internet banking facilities, as well as the social media platforms of Facebook to advertise their products and services, and these are adequately linked via their web pages. The entrepreneurs are well-informed, modern entrepreneurs who research and decide on the tools and applications that will work best for them. The author's publisher and the musician discussed earlier utilise all possible visual and digital applications to feature previews of books, music, videos or tours. It is very interesting and encouraging to discern how detailed and informative their social media campaigns are - a major contribution to their success.

On the other hand, the Kenyan business/retail platform is also keeping pace with South African entrepreneurs, but owing to the poor use of online payment, they have incorporated the use of m-commerce through the M-Pesa mobile payment mode in their business transactions. When investigating most of the businesses on social platforms, it becomes apparent that they are mostly run by expatriate students who have embraced technology, thereby enabling local entrepreneurs to incorporate this modern technology in an informal manner through Facebook personal pages, before raising funds to register the businesses on a more formal footing.

However, the Nigerian business space is interesting, and this is due to entrepreneurs who have incorporated website and social pages, and have used personal pages because of issues of trust and confidentiality existing in that region. The entrepreneurs know that they or their followers or 'friends' are people who personally know them and thus can identify with the person behind the page, unlike on a business page, where the individual behind the page (the administrator), is largely anonymous. The late renowned Nigerian author, Chinua Achebe, still has a presence on Facebook and on a website, courtesy of his publisher, Random House. Of further note is that Nigerian entrepreneurs do not utilise Twitter. Twitter is used in the corporate and social world in Nigeria, but not as a tool for entrepreneurship.

Social media platforms and the Internet are a very economical means for modern entrepreneurs to gain financial rewards. Modern African entrepreneurs should be cognisant of the existence of a considerable amount of free information on various websites, and entrepreneurs should be encouraged to invest a little time to educate and train themselves about social media and its applications to business. There is free information online regarding various social platforms and tools available for incorporating e-commerce and m-commerce into their ventures. Although e-commerce and $\mathrm{m}$-commerce platforms have been adopted on the African continent, there is still much to be done in this regard.

\section{Conclusion}

Social media platforms are here to stay, with the future being digital marketing through the use of technology, thus making it essential for modern African entrepreneurs to embrace technology through the Internet, and via social media platforms and tools, to enable them obtain and sustain an overall strategic advantage in their businesses. The trend of incorporating technology through the Internet and social media platforms has been observed, and is applicable to both the informal and formal business sectors. This phenomenon has been made possible owing to faster, cheaper Internet speeds and data offered by the major telecommunications companies and operators in Africa. This has enabled the majority of the global, modern, and widely travelled African youth, to return back to their respective countries, to harness and incorporate what they have learned through their worldwide travels, and to achieve financial success through social media platforms. Easy, reliable and relevant communication with both current and prospective clients is effected promptly, effectively, efficiently and in real time.

\section{References}

Africa Report [The] 2013. Start Up - Deeds Done in Nairobi. The Africa Report, Monthly, December/January 2013/2014.

Coyle D 2001. Paradoxes of Prosperity: Why the New Capitalism Benefits All. New York: Texere.

Ekekwe N 2011. Nuture entrepreneurs in Africa (online). Harvard Business Review Blog Network. [Online] Available: http://blogs.hbr.org/2011/02/nurture-entrepreneurs-in-afric/ (Retrieved: 6/9/2011).

Fick DS 2002. Entrepreneurship in Africa: A Study of Successes. Westport: CT: Quorum Books.

Gollamudi R 2012. Mobilizing entrepreneurship. Innovations: Special Edition for SOCAP12, 7(4): 13-20, Fall.

Green A 2011. Infographic: Social Media for Business Statistics. [Online] Available: http://www.creditdonkey.com/business-socialmedia.html (Retrieved: 5/9/2011).

Johnson-Elie T 2013. Women and Social Media (online) Avaliable: http://blog.marketwired.com/2013/04/19/women-social-media/ 
(Retrieved 3/9/2013).

Juma C 2011. Africa's new engine: Africa looks to its middle-class consumers to drive prosperity. Finance and Development, 48(4): 611.

Kanaiya S 2011. Impact Investors Pile in to Find Businesses that can Deliver Results on Every Front. Business Daily Africa, Daily, 27, May 2011.

Karrer-Rueedi E, Trueb D 2011. Empowering Micro-entrepreneurs and Small Businesses through Mobile Phones in emerging markets and Developing countries. ADTF Journal, 8(3/4): 13-18.

Komunte M, Rwashana AS, Nabukenya J 2012. Comparative analysis of mobile usage among women entrepreneurs in Uganda and Kenya. African Journal of Computer \& ICT, 5(5): 74-86, September.

Kusimba S, Chaggar H, Gross E, Kunyu G 2013. Social Networks of Mobile Money in Kenya. Irvine, CA: Institute of Mobile Money, Technology and Financial Inclusion (IMFTI).

Legatum Institute 2011. The Role of Entrepreneurship and Opportunity in Sub-Saharan Africa [Online] Available: http://www.li.com/publications/entrepreneurship-in-sub-saharan-africa (Retrieved: 31/8/2011).

Luiz J 2010. Infrastructure investment and its performance in Africa over the course of the twentieth century. International Journal of Social Economics, 37(7): 512-536.

Marsden K 1990. African Entrepreneurs: Pioneers of Development. Discussion Paper no. 9, October 1990. Washington, DC: World Bank, International Finance Corporation.

Michira M 2011. High Fliers Must Know their Business. Business Daily Africa, Daily, May 27, 2011.

Mulunda L 2012. The Queen of Africa Reboots. Forbes Africa, Monthly, February 1, 2012, pp. 16-20.

Padmannavar SS 2011. A review on e-commerce empowering women's [sic]. International Journal of Computer Science and Telecommunications, 2(8): 74-78, November.

Reed F 2011. SMB's Continue to Increase Social Media Use [online] Available: http://www.marketingpilgrim.com/2011/04/smbscontinue-to-increase-social-media-use.html (Retrieved: 9/9/2011).

Roxburgh C, Dörr N, Leke A, Tazi-Riffi A, Van Wamelen A, Lund S, Chironga M, Alatovik T, Atkins C, Terfous N, Zeino-Mahmalat T 2010. Lions on the Move: The Progress and Potential for African Economies. June 2010. Washington, DC: McKinsey Global Institute.

Saren M 2011. Marketing empowerment and exclusion in the information age. Market Intelligence \& Planning, 29(1):39-48.

Webster FE 1992. The changing role of marketing in the corporation. Journal of Marketing, 56(4): 1-7, October.

Weeks JR 2010. Women Business Owners Embrace Social Media Marketing (Online) Available: http://thewomenablerblog.com/2010/12/13/women-busines-owners-embrace-social-media-marketing/ (Retrieved: 3/9/2013).

West DM 2012. How Mobile Technology Is Driving Global Entrepreneurship. October 23. Washington, DC: Brookings Institution.

World Bank 2012. Information and Communications for Development 2012: Maximizing Mobile. IC4D 2012 (online) Available: http://www.worldbank.org/ict//C4D2012 (Retrieved: 3/6/2013). 